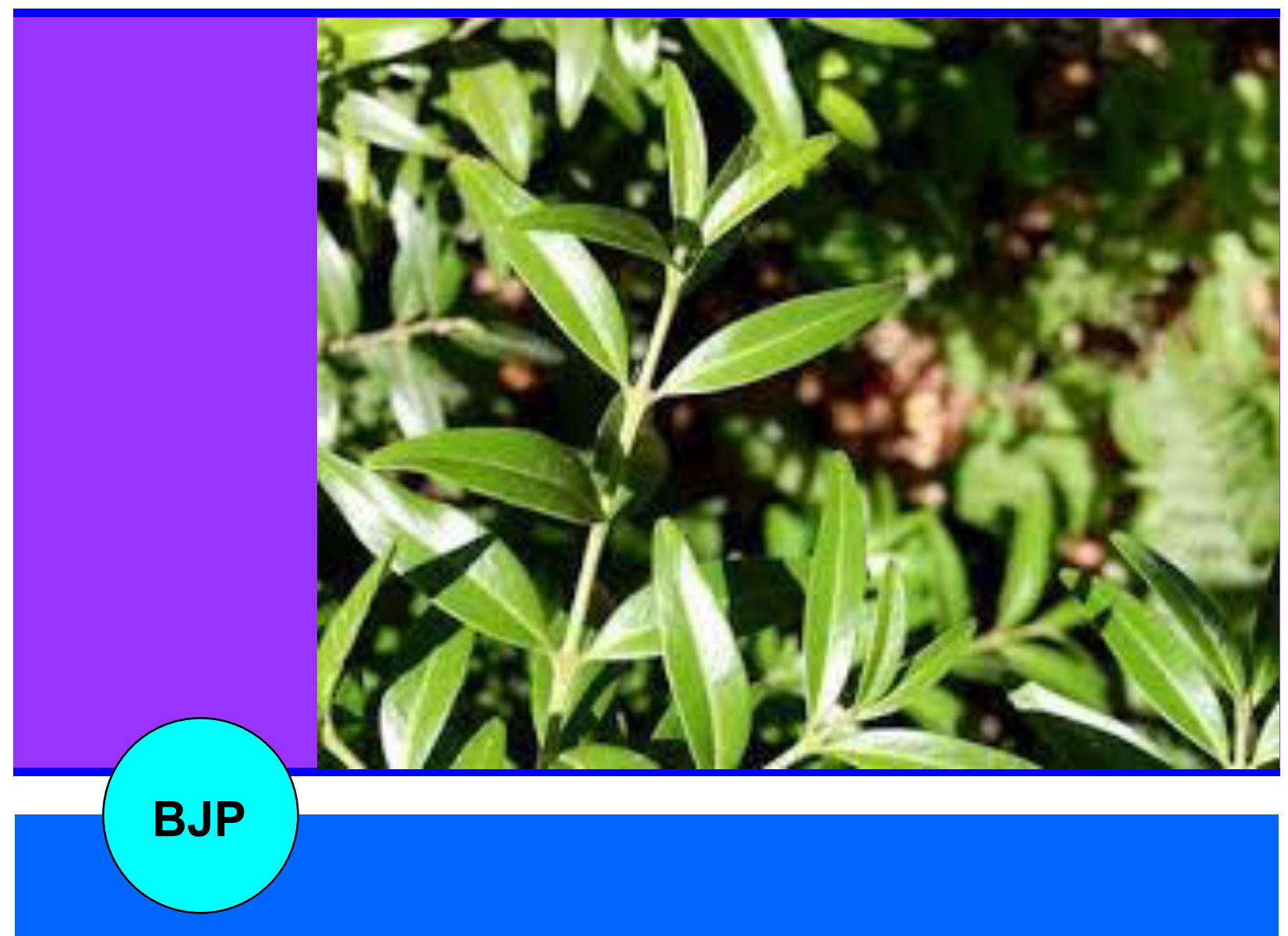

Bangladesh Journal of Pharmacology

Research Article

Pharmacological basis for the folkloric uses of Buxus wallichiana in gastrointestinal, respiratory and vascular disorders 
Abstracted/indexed in Academic Search Complete, Agroforestry Abstracts, Asia Journals Online, Bangladesh Journals Online, Biological Abstracts, BIOSIS Previews, CAB Abstracts, Current Abstracts, Directory of Open Access Journals, EMBASE/Excerpta Medica, Google Scholar, HINARI (WHO), International Pharmaceutical Abstracts, Open J-gate, Science Citation Index Expanded, SCOPUS and Social Sciences Citation Index

ISSN: $1991-0088$

\title{
Pharmacological basis for the folkloric uses of Buxus wallichiana in gastrointestinal, respiratory and vascular disorders
}

\author{
Musaddique Hussain ${ }^{1,2}$, Shahid Masood Raza ${ }^{2}$ and Khalid Hussain Janbaz' \\ ${ }^{1}$ Faculty of Pharmacy, Bahauddin Zakariya University, Multan, Pakistan; ${ }^{2}$ School of Pharmacy, The University of \\ Faisalabad, Faisalabad, Pakistan.
}

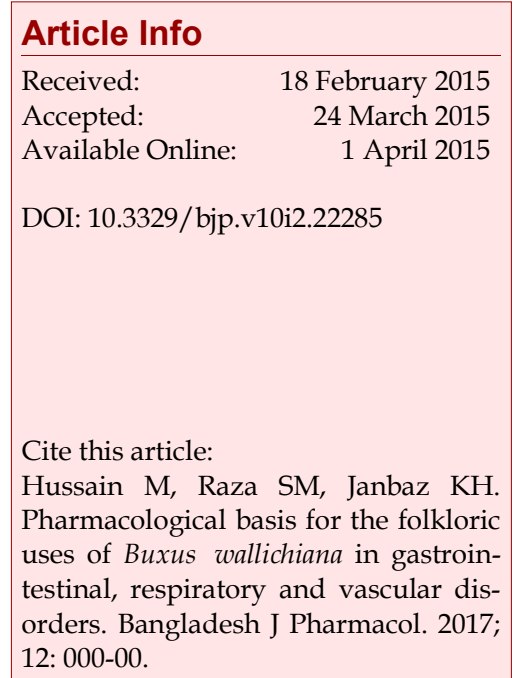

\section{Article Info}

Received:

Accepted:

DOI: 10.3329 / bjp.v10i2.22285

12: $000-00$

\begin{abstract}
In vitro study was carried out to explore the pharmacological basis of crude extract of Buxus wallichiana for its folkloric uses in gastrointestinal, respiratory and vascular disorders. In jejunum preparations, crude extract $(0.03 \pm 1.0 \mathrm{mg} /$ $\mathrm{mL}$ ) caused a transient spasmogenic effect followed by the spasmolytic effect at higher doses (3.0-10 mg/mL). In atropinized jejunum preparation, crude extract inhibited the spontaneous and $\mathrm{K}^{+}(80 \mathrm{mM})$-induced contraction, suggesting that spasmolytic effect is mediated through the $\mathrm{Ca}^{+2}$-channel blockade. The $\mathrm{Ca}^{+2}$-channel blockade effect was confirmed when pretreatment of tissue with extract produced a dose-dependent shift in $\mathrm{Ca}^{+2}$ concentrationresponse curves to the right, similarly as verapamil. Furthermore, crude extract exhibited non-specific relaxant effect on carbachol- $(1 \mu \mathrm{M})$ and $\mathrm{K}^{+}(80$ $\mathrm{mM}$ )-induced tracheal contractions, suggesting the coexistence of anticholinergic and $\mathrm{Ca}^{+2}$-antagonistic properties. Moreover, it relaxed the $\mathrm{K}^{+}(80 \mathrm{mM})$ and phenylephrine $(1 \mu \mathrm{M})$-induced contraction in rabbit aorta, suggesting the $\mathrm{Ca}^{+2}$-channel blockade. These findings may validate the folkloric uses of $B$. wallichiana in constipation, bronchitis, asthma and hypertension.
\end{abstract}

\section{Introduction}

Buxus wallichiana Baill. belonging to family Buxaceae, commonly known as Himalayan boxwood and shamshaad (Khare, 2007). Photochemical study revealed the presence of buxantine, buxiramin D, buxemenol E, buwandrine $\mathrm{F}$, buxindine $\mathrm{F}$, buxamine $\mathrm{F}$, buxaltine $\mathrm{H}$, (+)-16a, 31-diacetylbuxadine and semperviraminol (Kvaltinova et al., 1991; Husain et al., 1992; Rahman et al., 1999; Ata et al., 2002). Plant is traditionally used as laxative, diuretic, sedative, vermifuge, toothache, analgesic, anti-rheumatic, diaphoretic as well as used to treat hypertension and bronchitis, asthma and airway congestion (Kritikar and Basu, 1989; Chopra et al., 1992; Fleming, 1999; Khare, 2007).

Despite the popular medicinal uses of B. wallichiana, no pharmacological data are available with respect to its usefulness in GIT motility, airway and vascular system disorders. This study was undertaken to investigate and validate the mechanisms mediating its medicinal uses in constipation, asthma, bronchitis and hypertension.

\section{Material and Methods \\ Plant material and extraction}

The wood of $B$. wallichiana was collected from Faisalabad, Pakistan in May, 2014 and identified by expert botanist at Botany Department, UAF, Faisalabad. The plant wood was freed from debris and adulterants by hand picking and grinded into coarse powder (\#40) by herbal grinder.

Triple maceration procedure was adopted for extraction, by macerating powder with $80 \%$ aqueous-methanol in rotary orbital shaker, at room temperature 
(Hussain et al., 2013). After filtration through Whatman No. 1 filter paper, filtrate was concentrated in a rotary evaporator attached with a vacuum pump and a recirculation chiller, under reduced pressure at $37^{\circ} \mathrm{C}$ to dark brown thick syrup consistency; which was subsequently lyophilized to remove moisture contents with approximate yield of $18.3 \%$.

\section{Animals and housing conditions}

Animals $(\hat{\jmath} /+)$ inclu-ding, rabbits $(1.0-1.7 \mathrm{~kg}$, age limit between 5 to 7 months) and mice (Swiss albino 35-45 g) were provided with tap water ad libitum and standard diet and housed under controlled environmental condition $\left(25-28^{\circ} \mathrm{C}\right)$ at the animal house of School of Pharmacy, The University of Faisalabad, Faisalabad. Before the commencement of experiments, food was withdrawn from all animals but had free access to water. The rabbits were dissected to remove trachea, jejunum and aorta for in vitro experiments. All the experiments were performed by following ruling of Institute of Laboratory Animal Resources, Commission on Life Sciences (National Research Council, 1996).

\section{Standard drugs and chemicals used}

Highest purity and research grade solvents, chemicals and drugs were used in the experiments. Following chemicals and drugs, i.e., atropine sulfate, acetylcholine chloride, carbachol, potassium chloride, magnesium chloride, verapamil hydrochloride, ethylene diamine tetra-acetic acid (EDTA) and phenylephrine, were purchased from Sigma Chemicals Co. USA. Ammonium hydroxide, sodium chloride and sodium hydroxide were purchased from BDH Laboratory supplies, England. Glucose, dimethyl sulfoxide, calcium chloride, magnesium sulfate, dichloromethane, potassium dihydrogen phosphate, sodium bicarbonate, sodium dihydrogen phosphate and methanol were obtained from Merck, Germany.

\section{Acute toxicity test}

For the acute toxicity testing, twenty mice were divided into four groups (each 5). Group 1 (negative control) was given normal saline $(0.9 \% \mathrm{NaCl} ; 10 \mathrm{~mL} / \mathrm{kg})$ orally whereas group 2, 3 and 4 (test groups) were orally administered with 1,3 and $5 \mathrm{~g} / \mathrm{kg}$ of $B$. wallichiana, respectively. All 4 groups were kept under regular observation for possible mortality and toxic effects as gastrointestinal spasms, diarrhea, anorexia and behavioral changes for 24 hours

\section{In vitro experiments}

\section{Spasmogenic and/or spasmolytic activity}

Plant extract was tested on isolated rabbit jejunum preparations for possible presence of spasmogenic and/ or spasmolytic activity, as previously described (Hussain et al., 2014). A preload of $1 \mathrm{~g}$ was applied to isolated rabbit jejunum segments $(2-3 \mathrm{~cm})$ suspended in tissue baths containing Tyrode's solution, aerated with carbogen $\left(37^{\circ} \mathrm{C}\right)$. Stabilized rabbit jejunum preparations exhibit spontaneous rhythmic contractions and were tested for spasmogenic and/or spasmolytic effect without application of an agonist (Arshad et al., 2012; Janbaz et al., 2014a). The contractile effect of the plant material was assessed as the percent of the maximum effect produced by the control drug, acetylcholine (1.0 $\mu \mathrm{M})$.

\section{Determination of $\mathrm{Ca}^{+2}$ channel blocking activity}

To assess whether the sapsmolytic activity of the plant extract was through calcium channel blockade, the tissue preparation were depolarized by exposing to high concentration of $\mathrm{KCl}$, i.e., $\mathrm{K}^{+}(80 \mathrm{mM})$, resulting in appearance of sustained contraction as previously described (Farre et al., 1991).

\section{Bronchodilator activity}

The bronchodilator effect of the plant extract was assessed by using isolated rabbit trachea preparations (2-3 mm width), suspended in tissue baths containing normal Kreb's solution ( $\mathrm{pH} 7.4$ ), aerated with carbogen (Gilani et al., 2005). Afterwards, stabilized tissue preparations were exposed to $\mathrm{K}^{+}(80 \mathrm{mM})$ - and carbachol $(1 \mu \mathrm{M})$-for stabilization with a dose interval of $45 \mathrm{~min}$. The plant extract was applied on the obtained sustained contractions for possible relaxant effect. The standard drug with $\mathrm{Ca}^{2+}$ channel blocking effect (verapamil) was tested on $\mathrm{K}^{+}(80 \mathrm{mM})$ - and carbachol $(1 \mu \mathrm{M})$-induced spastic contractions in order to confirm the possible mechanism of action.

\section{Vasodilator activity}

The vasodilator/vasoconstrictor effect were studied by application of plant extract to tissue bath containing isolated rabbit thoracic aorta preparations $(2-3 \mathrm{~mm}$ wide) in cumulative manner, already exposed to $\mathrm{K}^{+}(80$ $\mathrm{mM})$ - and phenylephrine $(1 \mu \mathrm{M})$ - for stabilization with a dose interval of $45 \mathrm{~min}$ (Janbaz et al., 2014b).

\section{Data analysis and statistics}

The data is expressed as mean \pm SEM and EC $_{50}$ (median effective concentration) values are given with $95 \%$ confidence intervals (95\% CI) and the logarithmic dose response curves of different treatments were then plotted using computer software "Graphpad Prism" version 6, (Graph Pad Software, USA). Concentrationresponse curves were analyzed by nonlinear regression sigmoidal response curve (variable slope). Student $t$-test was applied for assessment of the observations. $\mathrm{P}<0.01$ was believed to be statistically significant.

\section{Results}

Acute toxicity of $B$. wallichiana was tested at different doses $(1,3$ and $5 \mathrm{~g} / \mathrm{kg}$ ); there was no mortality and 
change in animal behavior up to the dose as high as 5 $\mathrm{g} / \mathrm{kg}$, indicating that the plant is safe up to the maximal tested dose and is higher than the normal therapeutic dose.

Crude extract of $B$. wallichiana showed the spasmogenic effect on spontaneously contracting isolated rabbit jejunum preparations $(0.03-1.0 \mathrm{mg} / \mathrm{mL})$, which did not

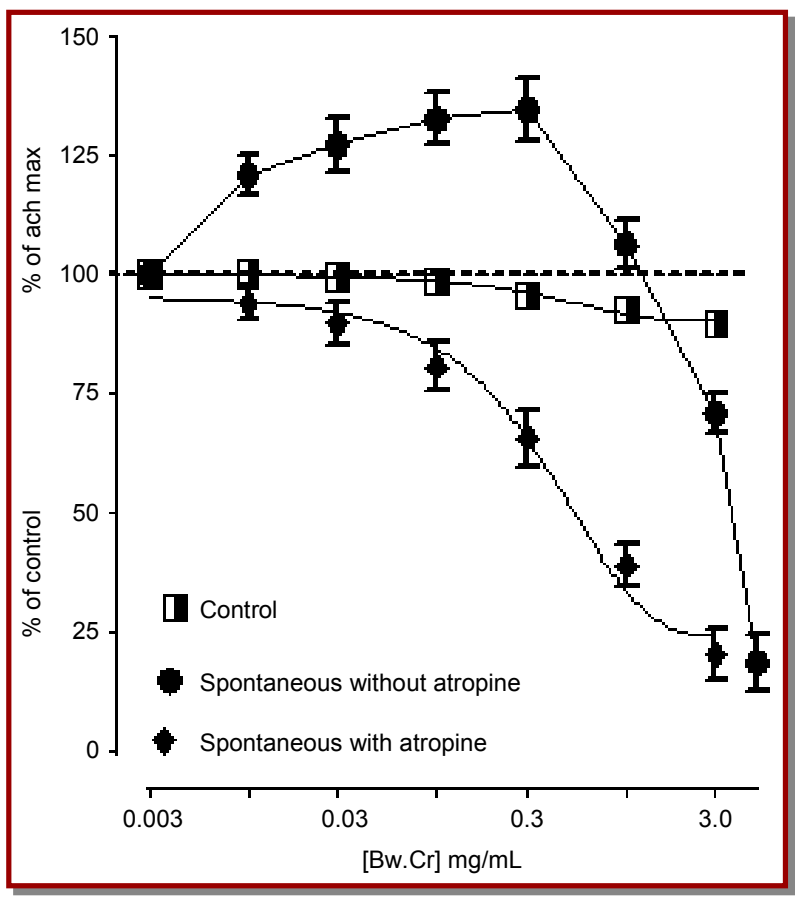

Figure 1: Concentration-response curves, showing the effect of crude extract of $B$. wallichiana in the absence and presence of atropine $(0.1 \mu \mathrm{M})$ on spontaneously contracting isolated rabbit jejunum. The spasmogenic responses are expressed as percent of acetylcholine maximum (Ach Max) (values are expressed as mean $\pm S E M, n=3$ )

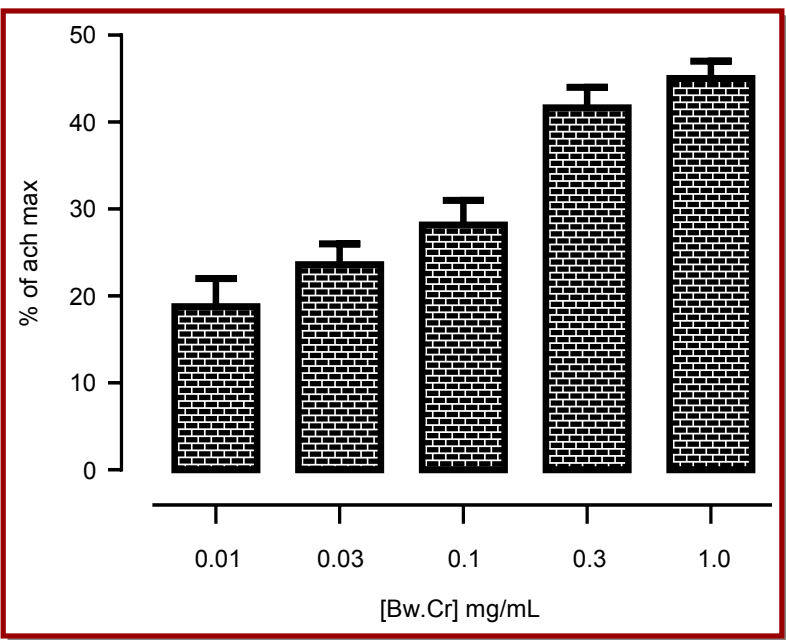

Figure 2: Bar diagram showing the effect of the crude extract of $B$. wallichiana in comparison to the acetylcholine maximum response in isolated rabbit jejunum preparation (values are expressed as mean \pm SEM, $n=3$ ) sustained and was subsequently followed by spasmolytic effect at the next higher dose $(3-10 \mathrm{mg} / \mathrm{mL})$ with $\mathrm{EC}_{50}$ of $2.87 \mathrm{mg} / \mathrm{mL}$ (95\% CI: 2.12-3.35, n=3) (Figure 1). The observed contractile responses to plant extract was expressed as percentage of the maximal response to acetylcholine $(0.3 \mu \mathrm{M})$, i.e. $15.50 \pm 0.7,21.17 \pm 1.7,25.30$ $\pm 1.7,39.3 \pm 1.2$ and $43.23 \pm 5.2$ (mean \pm SEM, $n=3$ ), at the dose range of $0.01,03,0.1,0.3$ and $1.0 \mathrm{mg} / \mathrm{mL}$ respectively (Figure 2). In the presence of atropine $(0.1$ $\mu \mathrm{M})$, spasmogenic effect was abolished while the spasmolytic effect was observed with $\mathrm{EC}_{50}$ of $1.17 \mathrm{mg} /$ mL (95\% CI: 0.42-1.95, n=3) (Figure 1).

When tested against $\mathrm{K}^{+}(80 \mathrm{mM})$-induced contractions, crude extract caused the dose dependent relaxation with $\mathrm{EC}_{50}$ of $1.6 \mathrm{mg} / \mathrm{mL}$ (95\% CI: 1.02-2.45, n=3), while verapamil, (positive control) inhibited the $\mathrm{K}^{+}(80 \mathrm{mM})$ induced contractions, with $\mathrm{EC}_{50}$ of $0.17 \mathrm{mg} / \mathrm{mL}(95 \%$ CI: $0.09-0.35, n=3$ ) (Figure 3). Crude extract shifted the $\mathrm{Ca}^{+2}$-concentration response curves at the dose range of $0.3-3.0 \mathrm{mg} / \mathrm{mL}(\mathrm{n}=3)$ to the right, like that caused by verapamil at $0.1-1.0 \mu \mathrm{M}(\mathrm{n}=3)$ (Figure 4).

Crude extract of B. wallichiana, on application to isolated rabbit tracheal preparations exhibited the concentration dependent relaxant effect on $\mathrm{K}^{+}(80 \mathrm{mM})$ and carbachol $(1 \mu \mathrm{M})$-induced contractions, with $\mathrm{EC}_{50}$ value of $0.45 \mathrm{mg} / \mathrm{mL}(0.11-0.72,95 \% \mathrm{CI}, \mathrm{n}=3)$ and 1.13 $\mathrm{mg} / \mathrm{mL}(0.63-1.62,95 \% \mathrm{CI}, \mathrm{n}=3)$ respectively, being more potent against $\mathrm{K}^{+}(80 \mathrm{mM})$ - (Figure $\left.5 \mathrm{~A}\right)$, whereas verapamil also exhibited the similar pattern of inhibition against $\mathrm{K}^{+}(80 \mathrm{mM})$ - and carbachol $(1 \mu \mathrm{M})$-induced contractions with $\mathrm{EC}_{50}$ value of $0.12 \mathrm{mg} / \mathrm{mL}(0.03-0.4$,



Figure 3: Concentration-dependent inhibitory effect of the crude extract of $B$. wallichiana and verapamil against $\mathrm{K}^{+}(80$ $\mathrm{mM}$ )-induced contractions in isolated rabbit jejunum preparations (values are expressed as mean \pm SEM, $n=3$ ) 

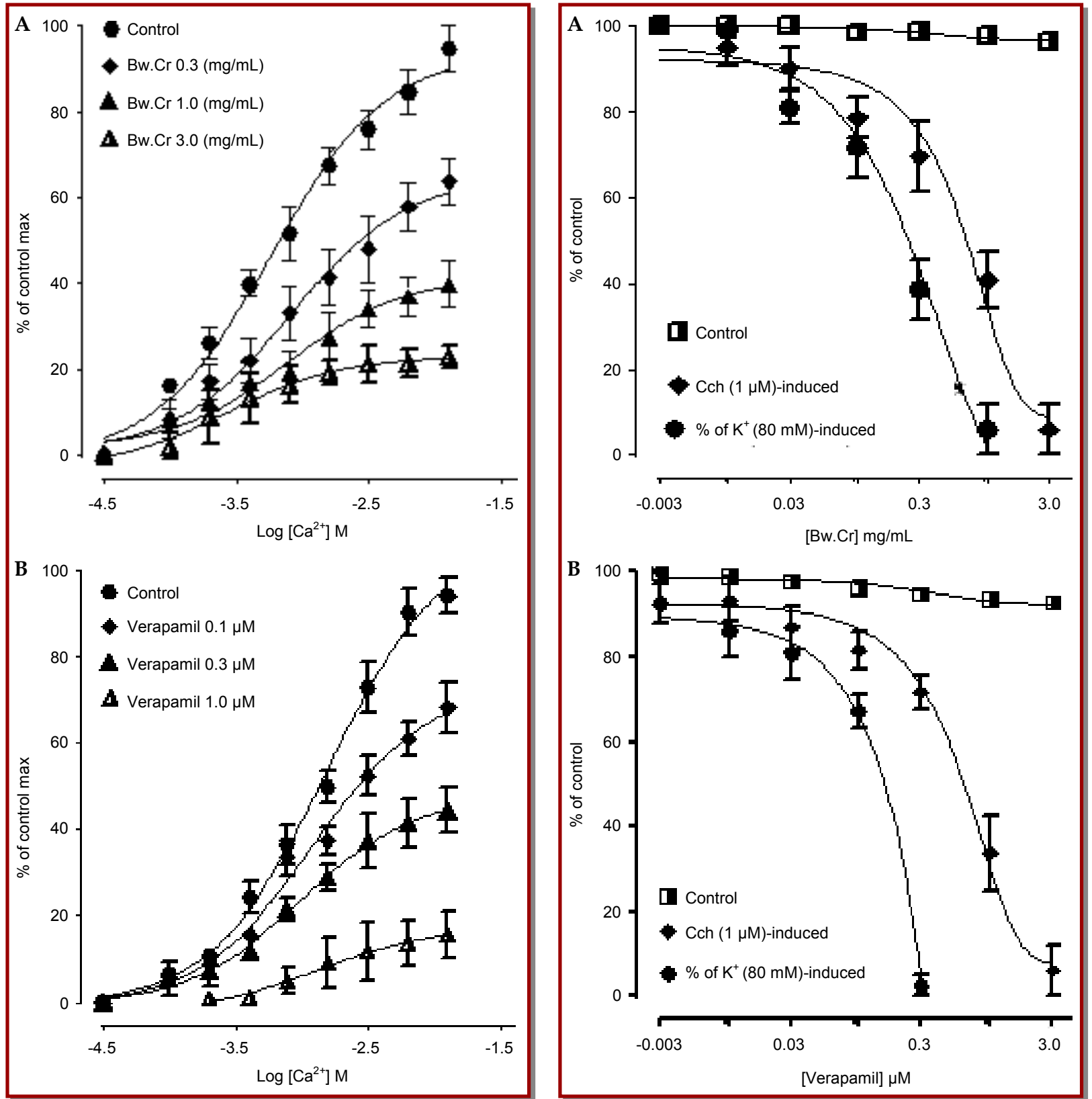

Figure 4: Concentration-response curves of $\mathrm{Ca}^{+2}$ in the absence and presence of different concentrations of (A) crude extract of B. wallichiana and (B) verapamil in isolated rabbit jejunum preparations (values are expressed as mean $\pm S E M, n$ $=3$ )

Figure 5: Concentration-response curves showing inhibitory effect of (A) crude extract of B. wallichiana and (B) verapamil against $\mathrm{K}^{+}(80 \mathrm{mM})$ - and carbachol $(1 \mu \mathrm{M})$-induced contractions in isolated rabbit trachea preparations (values are expressed as mean $\pm S E M, n=3$ )

95\% CI, n = 3) and $1.12 \mathrm{mg} / \mathrm{mL}(0.59-1.94,95 \% \mathrm{CI}, \mathrm{n}=$ 3) respectively (Figure $5 B$ ).

Crude extract of B. wallichiana, on application to isolated rabbit aorta preparations exhibited the concentration dependent relaxant effect on $\mathrm{K}^{+}(80 \mathrm{mM})$ - and phenylephrine $(1 \mu \mathrm{M})$-induced contractions, with $\mathrm{EC}_{50}$ value of $0.28 \mathrm{mg} / \mathrm{mL}(0.07-0.63,95 \% \mathrm{CI}, \mathrm{n}=3)$ and 2.58 $\mathrm{mg} / \mathrm{mL}(1.72-3.21,95 \% \mathrm{CI}, \mathrm{n}=3$ ) respectively (Figure $6 \mathrm{~A})$, whereas verapamil on application to the $\mathrm{K}^{+}(80$

$\mathrm{mM})$ - and phenylephrine $(1 \mu \mathrm{M})$-induced contractions showed relaxant effect with $\mathrm{EC}_{50}$ value of $0.15 \mathrm{mg} / \mathrm{mL}$ (0.02-0.42, 95\% CI, $\mathrm{n}=3$ ) and $1.25 \mathrm{mg} / \mathrm{mL}(0.62-2.11$, $95 \% \mathrm{CI}, \mathrm{n}=3$ ) respectively (Figure $6 \mathrm{~B}$ ). Crude extract shifted the $\mathrm{Ca}^{+2}$-concentration response curves at the dose range of $0.3-1.0 \mathrm{mg} / \mathrm{mL}(\mathrm{n}=3)$ to the right, like that caused by verapamil at $0.1-0.3 \mu \mathrm{M}(\mathrm{n}=3)$, thus conforming that observed relaxant effect was likely to be mediated through calcium channel blocking effect (Figure 7 A \& B). 


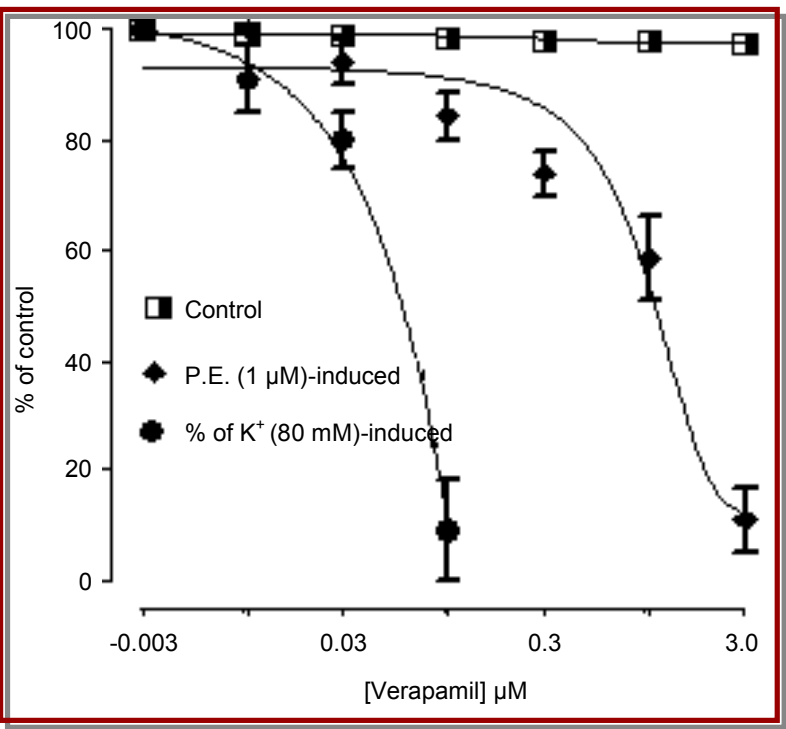

Figure 6: Concentration-response curves showing inhibitory effect of (A) crude extract of B. wallichiana and (B) verapamil against $\mathrm{K}^{+}(80 \mathrm{mM})$ - and phenylephrine $(1 \mu \mathrm{M})$-induced contractions in isolated rabbit aortic preparations (values are expressed as mean $\pm \mathrm{SEM}, \mathrm{n}=3$ )

\section{Discussion}

Medicinal plants are being widely used throughout the world as a source of potent medicinal agent for the health care. B. wallichiana has folkloric repute to be beneficial in the management of multiple ailments pertaining to gastrointestinal (constipation), respiratory (bronchitis, asthma and airway congestion) and vascular system (hypertension). Present research was undertaken for the scientific evaluation and validation of these folkloric claims through an exploration of the possible mechanism(s) of action.

Keeping in view of traditional uses, pharmacological study of crude extract of $B$. wallichiana was carried out on spontaneously contracting isolated rabbit jejunum preparations, to evaluate its possible effect, initially it produced the spasmogenic effect (contractile effect), which is usually mediated through cholinergic mechanism as like by acetylcholine (Gilani et al., 2005; Hussain et al., 2014), so for the conformation of this mechanism, spontaneous contracting jejunum preparations were pretreated with $0.1 \mu \mathrm{M}$ of muscarinic receptor antagonist (atropine) (Delmendo et al., 1989), abolished the stimulatory effect of plant extract, which indicates that the $B$. wallichiana causes the gut stimulation via cholinergic pathway (Janbaz et al., 2012). Acetylcholine is a neurotransmitter released by the parasympathetic nervous system; regulate the peristaltic movement of the gut by acting on $\mathrm{M}_{3}$ muscarinic receptor while atropine (antagonist) blocks muscarinic receptors (Brown and Taylor, 1996). The observed spasmogenic effect of $B$. wallichiana validates its tradi- tional use as laxative agent in the hypo-motility disorder of the gut, i.e., constipation. The spasmogenic effect was followed by the spasmolytic effect at next higher doses of the extract, indicating the co-existence of spasmogenic and spasmolytic constituent(s), which is pro-


Figure 7: Concentration-response curves of $\mathrm{Ca}^{+2}$ in the absence and presence of different concentrations of (A) crude extract of B. wallichiana and (B) verapamil in isolated rabbit aorta preparations (values are expressed as mean \pm SEM, $n=3$ )

bably meant by the nature not to allow the spasmogenic effect going beyond the constipation, particularly at higher doses (Ghayur and Giliani, 2005).

In the previous studies, we observed that spasmolytic effect of medicinal plants is usually mediated through 
$\mathrm{Ca}^{+2}$ channels blockade (Gilani et al., 1994; Janbaz et al., 2012). To elucidate whether the spasmolytic effect of the extract is also mediated through the $\mathrm{Ca}^{+2}$ channels blockade, its extract was tested on $\mathrm{K}^{+}(80 \mathrm{mM})$-induced contractions which is known to cause smooth muscles contractions through opening of the voltage dependent L-type $\mathrm{Ca}^{+2}$ channels, thus allowing the influx of extracellular $\mathrm{Ca}^{+2}$ causing a contractile effect (Bolton, 1979) and substances inhibiting the $\mathrm{K}^{+}(80 \mathrm{mM})$-induced contraction are known as $\mathrm{Ca}^{+2}$ channels blockers, i.e., inhibitor of $\mathrm{Ca}^{+2}$ influx (Godfraind et al., 1986; Okumura et al., 1993; Shah et al., 2011). Crude extract of $B$. wallichiana, like verapamil (standard calcium channel blocker), relaxed the $\mathrm{K}^{+}(80 \mathrm{mM})$-induced contractions, indicating the $\mathrm{Ca}^{+2}$ channel blocking action. The $\mathrm{Ca}^{+2}$ channels blocking effect of $B$. wallichiana was further confirmed when it shifted the $\mathrm{Ca}^{+2}$-concentration response curves to the right, like that caused by positive control (verapamil).

Based upon the traditional uses of B. wallichiana for the relief reparatory tract disorders including bronchitis, asthma and airway congestion, the plant extract was evaluated for its possible bronchodilator effect on sustained contractions induced on addition of carbachol $(1 \mu \mathrm{M})$ and $\mathrm{K}^{+}(80 \mathrm{mM})$ to the tissue baths containing isolated rabbit trachea preparations and founded to produce relaxation in both of situations. The bronchodilator effect is likely to be mediated through $\mathrm{Ca}^{+2}$ channel blockade as $\mathrm{Ca}^{+2}$ channel blockers exert bronchodilator effect on hyperactive respiratory tract (Janbaz et al., 2014c).

Moreover, B. wallichiana exerted relaxant effect on isolated rabbit aortic preparations and also on $\mathrm{K}^{+}(80$ $\mathrm{mM})$ - and phenylephrine $(1 \mu \mathrm{M})$-induced contraction, elaborating the calcium channel blocking activity as $\mathrm{K}^{+}$ (80 $\mathrm{mM}$ )-induced contractions are mediated through the activation of $\mathrm{Ca}^{+2}$ channels as well as release of $\mathrm{Ca}^{+2}$ from endoplasmic reticulum, whereas mechanism underlying the phenylephrine $(1 \mu \mathrm{M})$-induced contraction is through the activation of a-adrenergic receptors and subsequent $\mathrm{Ca}^{+2}$ influx through the receptors mediated $\mathrm{Ca}^{+2}$ channels, hence suggesting its vasodilator effect possibly mediated through calcium channel blockade (Janbaz et al., 2014d).

Oral dose of B. wallichiana did not produced the lethality among the treated groups of mice up to tested dose of as high as $5 \mathrm{~g} / \mathrm{kg}$, which is much higher than the routinely used therapeutic dose. However, more detailed toxicity studies are required to justify the safety of this plant.

These data clearly shows that gut modulatory (stimulitory and inhibitory) and bronchodilator activities of $B$. wallichiana may be attributed due to blockade of $\mathrm{Ca}^{+2}$ channels and muscarinic receptors, whereas, vasodilator activity may be due to blockade of $\mathrm{Ca}^{+2}$ channels, though additional mechanism cannot be ruled out. Thus, this study provides sound pharmacological basis and mechanistic background to validate the folkloric use of $B$. wallichiana in the management of gastrointestinal, respiratory and vascular ailments such as constipation, bronchitis, airway congestion, asthma and hypertension.

\section{References}

Arshad U, Janbaz KH, Bashir S, Rehman NU, Mehmood MH, Gilani AH. Ethnopharmacological studies on Chrozophora prostrata in perspective of its folkloric reputation as purgative. Bangladesh J Pharmacol. 2012; 7: 243-48.

Ata A, Naz S, Choudhary MI, Rahman AU, Sener B, Turkoz S. New triterpenoidal alkaloids from Buxus sempervirens. Z Naturforsch. 2002; 57: 21-28.

Bolton TB. Mechanisms of action of transmitters and other substances on smooth muscle. Physiol Rev. 1979; 59: 606718 .

Brown JH, Taylor P. Muscarinic receptor agonists and antagonists. In: The pharmacological basis of therapeutics. Gilman AG, Hardman JG, Limbird LE, Molinoff PB, Ruddon RW (ed). New York, McGraw-Hill, 1996, pp 141-59.

Chopra RN, Ayer SL, Chopra IC. Glossary of Indian medicinal Plants. New Delhi, Council of Scientific and Industrial Research (CSIR), 1992, p 150.

Delmendo RE, Michel AD, Whiting RL. Affinity of muscarinic receptor antagonists for three putative muscarinic receptor binding sites. Br J Pharmacol. 1989; 96: 457-64.

Farre AJ, Colombo M, Fort M, Gutierrez B. Differential effects of various Ca2+ antagonists. Gen Pharmacol. 1991; 2: 177-81.

Fleming T. PDR for herbal medicines. New Jersey, Medical Economic Company, 1999, pp 702-03.

Ghayur MN, Gilani AH. Pharmacological basis for the medicinal use of ginger in gastrointestinal disorders. Dig Dis Sci. 2005; 50: 1889-97.

Gilani AH, Bashir S, Janbaz KH, Shah AJ. Presence of cholinergic and calcium channel blocking activities explains the traditional use of Hibiscus rosasinensis in constipation and diarrhea. J Ethnopharmacol. 2005; 102: 289-94.

Gilani AH, Janbaz KH, Zaman M, Lateef A, Suri, A, Ahmed HR. Possible presence of calcium channel blocker(s) in Rubia cordifolia: An indigenous medicinal plant. J Pak Med Assoc. 1994; 44: 82-85

Godfraind T, Miller R, Wibo M. Calcium antagonism and calcium entry blockade. Pharmacol Rev. 1986; 38: 321-26.

Husain A, Virman OP, Popli SP, Mishra LN, Gupta M, Srivastava GN, Abraham Z, Singh AK. Dictionary of medicinal plants. Lucknow, Central Institute of Medicinal and Aromatic Plants Publication, 1992, p 89.

Hussain M, Farooq U, Rashid M, Bakhsh H, Majeed A, Khan IA, Rana SL, Rehman M S, Aziz A. Antimicrobial activity of fresh latex juice and extract of Euphorbia hirta and Euphorbia 
thymifolia: An in vitro comparative study. Int J Pharma Sci. 2014; 4: 546-53.

Hussain M, Raza SM, Janbaz KH. Pharmacological evaluation and validation for the folkloric use of Oligochaeta ramose (Roxb.) in constipation and diarrhea. Bangladesh J Pharmacol. 2014; 9: 617-23.

Janbaz KH, Arif J, Saqib F, Imran I, Ashraf M, Zia-Ul-Haq M, De Feo V. In vitro and in vivo validation of ethnopharmacological uses of methanol extract of Isodon rugosus Wall. ex Benth (Lamiaceae). BMC Complement Altern Med. 2014d; 14: 71-83.

Janbaz KH, Haider S, Imran I, Zia-Ul-Haq M, De-Martino L, De-Feo V. Pharmacological evaluation of Prosopis cineraria (L.) Druce in gastrointestinal, respiratory, and vascular disorders. Evid Based Complement Alternat Med. 2012; 12: 1-7.

Janbaz KH, Hamid I, Gilani AH, Qadir MI. Spasmolytic, bronchodilator and vasodilator activities of aqueous-methanolic extract of Ocimum basilicum. Int J Agric Biol. 2014b; 16: $321-27$

Janbaz KH, Qayyum A, Saqib F, Imran I, Zia-Ul-Haq M, De Feo V. Bronchodilator, vasodilator and spasmolytic activities of Cymbopogon martini. J Physiol Pharmacol. 2014c; 65: 859-66.

Janbaz KH, Shabbir A, Mehmood MH, Gilani AH. Pharmacological basis for the medicinal use of Rhus coriaria in hyperactive gut disorders. Bangladesh J Pharmacol. 2014a; 9: 636-44.

Khare CP. Indian medicinal plants: An illustrated dictionary. Berlin/ Heidelberg, Springer, 2007, p 106.

Kiritikar KR, Basu BD. Indian medicinal plants. Blatter E, Caius JF, Mahaskr KS (ed). Vol III. 2nd ed. Dehradun, India, 1987, pp 2010-11.

Kvaltinova Z, Lukovie L, Machova M Fatranska M. Effect of steroidal alkaloid buxaminol $\mathrm{E}$ on blood pressure, acetyl cholinesterase activity and (tritiated) quinuclidinyl benzilate binding in cerebral cortex. Pharmacology 1991; 43: 20-25.

National Research Council. Guide for the care and use of laboratory animals. Washington DC, National Academy Press, 1996.

Okumura K, Ichihara K, Nagasaka M, Oda N, Tajima K. Calcium entry blocking activities of MPC-1304 and of its enantiomers and metabolites. Eur J Pharmacol. 1993; 235: 6974

Rahman AU, Ata A, Naz S, Choudhary MI, Sener B, Turkoz S. New steroidal alkaloids from the roots of Buxus simpervirens. J Nat Prod. 1999; 62: 665-69.

Shah AJ, Begum S, Hassan SI, Ali SN, Siddiqui BS, Gilani AH. Pharmacological basis for the medicinal use of Psidium guajava leave in hyperactive gut disorders. Bangladesh J Pharmacol. 2011; 6: 100-05. 